\title{
CHANGES IN URBAN SKYLINES AND PERCEPTION OF THE CITIZENS: A STUDY OF ISTANBUL
}

\author{
Zeynep Büşra Altuntaş ${ }^{1 *}$ and Deniz Erinsel Önder ${ }^{2}$ \\ ${ }^{1}$ M.Sc. Student, Yıldız Technical University, Turkey, zeynepbusraaltuntas@gmail.com \\ ${ }^{2}$ Prof. Dr., Yıldız Technical University, Turkey, erinselonder@gmail.com \\ ${ }^{*}$ Corresponding author
}

\begin{abstract}
Being a citizen or resident of a particular city or urban center does not only refer to a person's participation in the city but also encompasses their sense of belonging to and being a part of the city. In the perspective of urban space, the sense of urban belonging is an indicator of how people feel about themselves as part of the city, their feelings of urban consciousness, and their sense of responsibility toward the city and urbanized areas around it. Cities that have a recognized urban identity increase people's sense of belonging to them. As it happens, when citizens feel that they are a part of the city, they react to it with greater sensitivity. Therefore, creating cities where perception and identity are high affects urban life and contentment levels of its residents. Cities are living beings that evolve from the time of their first settlers and continue to develop and change as long as the city exists. Traces of the past can be found today in many cities as well as signs of the future they are seeking. Although all cities are made up of the same basic physical elements, their semantic structure, organizational principles, and relationships differ to give them their unique character. In other studies on cities, the perception of the city and its permanence are significantly affected by the visual characteristics of the city's skyline. Urban skylines have great importance for a city's esthetic texture and its evaluation. Maintaining a high quality in the texture of a city is important. Texture refers to the general way it looks, like the skyline, but also factors such as what materials it is built of, whether everything is close together or far apart, or whether the buildings are only a few stories tall or they are skyscrapers. Thus, how people perceive a city's identity can be profoundly affected not only by its urban skyline but also by other characteristics of its texture. This study examines citizens' perspective of the city skyline of Istanbul and measures their levels of contentedness given the rapidly changing skyline. To achieve this, surveys have been conducted with two groups of subjects. The first group included professionals in architectural disciplines such as architects, urban planners, interior designers, and landscape architects. The other group included members of other professions. The results revealed that none of the respondents are contented with the changing skyline of the city. They expressed discomfort and irritation about irregular settlements, the lack of green spaces, a lack of a common language of architecture, and the lack of a uniform scale for structures that are visible components of the city skyline. These issues prompt the respondents to not feel
\end{abstract}


like they are a part of the city. Therefore, it would be advantageous for the city leaders to seek more balance and cohesion in the development of the skyline in order to have a more meaningful, sensible, and livable city.

Keywords: urban skyline, city image, urban perception, urban identity.

\section{INTRODUCTION}

The population of cities has been increasing with internal migration and is dramatically high in metropolitan areas. The increase in population is driving vertical development in the city drastically changing city's skyline and making the rapid influx of people obvious.

The skyline of a city is its portrait, and this portrait is formed through the accumulation of different processes over time (Aksoy, 2009). Some basic elements that affect this change are the natural and constructed environments, socio-economic levels and chronological events that the city experiences over time. Additionally, laws, regulations, and urbanization policies of governments play an important role; these go through changes over time and have a considerable impact on city development. Cities are remolded through all of these processes that form the unique skylines showing us cities are living entities that change with time and populations. A skyline is an image of the top edge of something (Hasol, 2008, p. 442). In this case, it is literally the border where a city reaches from the land up into the sky. The skyline of a city contributes strongly to the branding and global recognition of a city. The more distinctive it is, the easier it is to remember. Ideally, a city has a certain line effect; the horizontal and vertical relationships help the stratification of the city, and the scales between the layers of a city are more readily obvious. For this reason, the skyline of a city is important for maintaining a positive perception of urban space among the residents.

If most of the structures are similar in a city, then the skyline becomes monotonous. On the other hand, if the structures are totally different from one another, the resulting skyline may not speak a common or harmonious language making the citizens uncomfortable and cause a sense of dissonance from the visual chaos. These are important reasons to develop a balance between fullness and emptiness and monotony and differentiation in the texture of a city, which has been studied in an esthetical analysis by Bostanci (Bostancı, 2008, p.84).

This study has analyzed the effects of changes on citizen perception, and their level of contentedness has been studied through recent examples in metropolitan Istanbul, which is a coastal city that changes constantly. To measure the level of contentedness, two different subject groups (as in the study mentioned above), professionals in architectural disciplines and members of other professions were asked to answer a survey consisting of both open-ended and close-ended questions. This study is important as it helps to understand the way citizens perceive Istanbul through their everyday experiences in the city. It measures their level of contentedness with the rapid changes in the city and reports citizen opinions on the situation. Bostancl's study forms the basis for further studies for better, more balanced city designs to improve citizen contentment because of conscious attention to develop a common architectural language with more holistic esthetics.

\section{CITY, ENVIRONMENT, THE IMAGE OF CITY AND SKYLINE}

\subsection{City and Urban Identity}

A city and its architecture do not typically just spring into being but develop over a long period of years (Cansever, 2015, p.72). In the process of gaining its shape over the years, the city is affected by elements such as legal regulations, population growth and decline, and social, cultural, political, and technical parameters and changes as it becomes a permanent residential area (Özdeş, 1985). There are important relationships among these elements for the formation of a beautiful city. Urban areas acquire meaning from differences in these relationships. What forms the character of a city and gives it its identity are those social and cultural differences of its long years of growth (Önem and Kılınçarslan, 2005).

Cities are made up of people from different cultures, social classes, and ways of living. They form a collective culture unique to the city as they settle and interact with one another in open spaces, streets, squares, buildings, and other public spaces. Therefore, the importance of the meaning of these places cannot be underestimated in terms of the interaction between society and individuals (Erdönmez, 2005, p.67). Physical and social environments are critical elements in the formation of a city and are greatly affected by cultural development that has a continuous relationship with it. (Figure 1). 


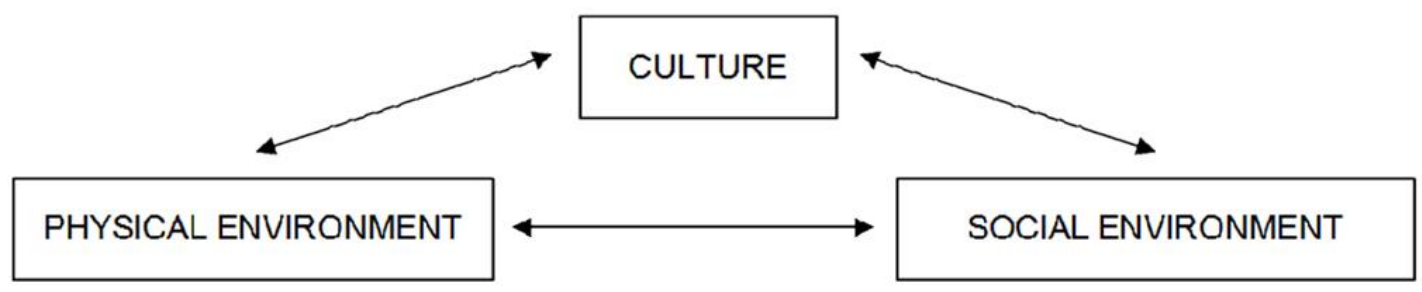

Fig. 1. Culture - Environment Relationship (Aksoy, 2009, p.8)

As a result of these interactions, a city's unique identity and elements become distinguished as living qualities (Rapaport, 1977). Culture and the identity of a city are not separate from one another.

Elements that form an urban identity can be categorized as natural, social, and the built environment (Önem and Kılınçarslan, 2005, p. 116). Elements of the natural environment consist of general condition, the geological location, its topographical character, climate, presence or absence of water, and the natural flora of the region. A city gains a meaningful identity from the uniqueness of these elements. Social factors of urban identity are individuals and society. Social factors that have an impact are those already described as the individuals who make up the broader society of the city as they adjust their values, traditions, customs, and habits to fit into the environment they live in. Personal and social identities in a city result from their background knowledge, experiences, wishes, and goals. Identity elements that come from the built environment reflect the needs of the city's population for an urban existence in an acceptable living space. The relationship of the elements of form, structure, texture, and materials (elements that forms the image of a city) of the natural and built environments are critical for people to recognize the identity of the city and to feel a part of it (Ocakçı, 1994 and 1995). (Figure 2)

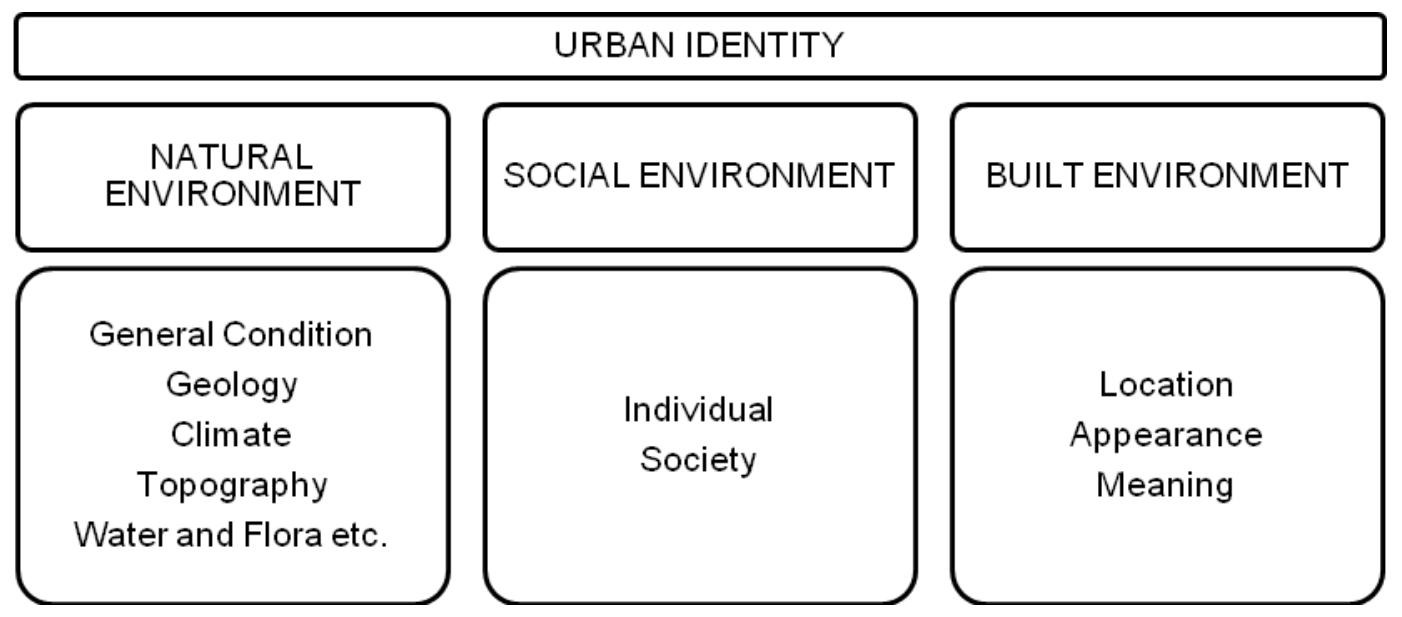

Fig. 2. Elements that Form the Identity of the City (Ocakçı, 1994 and 1995)

Today, communication among people has increased because of technology; information exchange and cultural transmission have become easier; and distances between places have shrunk. As a result, relationships between cities have improved and cities have become more similar because of rapid population growth and migration. Technology and rises in population have begun to erode personal identity (Bayramoğlu, 2010). The decreases of open and public spaces in the city, such as parks, gardens, and green spaces, have changed the identity of cities in a negative way as well. As urban populations increase, vertical construction increases and creates a dissonance between the old and the new in cities that have a rich historical texture but are also growing metropolises like Istanbul. The mismatch between new construction and historical texture in terms of form, experience, and social perception is reflected in the skyline of the city. Evidently, local citizens are disturbed by these changes.

\subsection{City Perception, Belonging, Aesthetics and Skyline}

The criteria for quality in natural and architectural design are important because they provide the aesthetic background for a city. According to Lynch, what makes a city memorable is the ease with which the city image can be recognized. Such recognition is made up of the amalgam of the factors that form the identity of the built environment of the city: designed elements such as paths, edges, districts, nodes, and landmarks (Lynch, 1960). The complement of the multi-factor relationships cause a city's design to mesh with its natural environment (climate, geography etc.), culture, history, religions, economic, social, and human 
elements. As mentioned before, cities are shaped through a long period of synthesis. In this process, there is a compilation of elements from different historical eras that shape the city either in a planned or spontaneous way and sometimes, in way that has a bit of both. Still, cities can gain esthetical value as a result of the connectivity that accompanies planned processes or natural unfettered development (Bostancı, 2008, pp 12).

That is why, in both individual and city-scale construction projects, space for human interaction should be well understood and accommodated in planning and designing. The use and availability of physical space is the foundation of individual perception of environment and forms the first impressions of the identity of the city that is formed with the perception and personalization of physical, social and cultural elements (Bayramoğlu, 2010).

Esthetics has various definitions, but all of them relate to the concept of being attractive or pleasing to one or more of the senses. Esthetic aspects of a city are related to the characteristics of the city and the level of spatial and visual interaction between those characteristics and the people. A skyline is actually a pile of images whose elements are compiled one on top of another where the bottom line is the earth and the top line is the sky. So, from a distance, when the city can be seen as a whole, it is the skyline that provides the first impression and hopefully the unique memory of the city as a whole (Bostancl, 2008, pp. 1-2).

As esthetics is related to people's likes and dislikes, it contains relativity and ambiguity as people are not alike. However, concepts like certainty, order, and proportion are esthetic features that are related to formal characteristics and make an evaluation more objective (Bostancl, 2008, p.6). Today, esthetics can be defined as "a study field of the subject-object relation as related to the feeling of contentedness, and the creation or the design of the object" (Şentürer, 2004, p. 106). While esthetic values were once analyzed from two different approaches, formal and symbolical esthetics in architecture, as the effort to understand the concept of esthetics has increased, it is now discussed in terms of "symbolic (semantic, associative), emotional and formal (plastic shape and perceptional shape) interactions, between construction-environment and people" (Oral, 2013, p.19).

While Bostancı argued that esthetics can be measured, she also defined characteristics of formal esthetics as variety, harmony, and clarity stating that harmony is actually a state of balance between clarity and variety. Her list of criteria that define variety and clarity includes the following: mass effects, line effects, vertical and horizontal effects, form and color features, hierarchy, dominant effects, repetition, similarity, rhythm, continuity, time, texture-pattern, shape-ground contrast, old-new contrast, natural-constructed texture contrast, scale-volume contrast, and proportion contrast. Symbolic esthetic features are grouped into meaning and function. Formal esthetical features are ones that can be measured using quantitative approaches, whereas symbolical features cannot be measured quantitatively (Bostancı, 2008, p.46).

One of the goals of this study was to measure the contentment levels from citizen-evaluations of the skyline according to esthetic aspects. To achieve this, a 5 point scale was created with various adjective pairs. Formal esthetic features of the skyline such as proportion, scale/volume, old-new contrast, harmony, clarity, vertical-horizontal effect, and contrast are listed as "formal" aspects. To determine space and identity perceptions, elements that form balance are given as "experiential" factors. To determine urban identity and the state of belonging, elements that included livability, identity, control, and peacefulness were in the "social" category.

\section{ISTANBUL AND ITS CHANGING SKYLINE}

The changings of İstanbul from the pre-fifteenth century (the late Ottoman era) up to 2000 is shown in Figure 2. In the pre-fifteenth century, Istanbul started to widen around the Bosporus and the historical peninsula. In 1950s, the city extended among the Marmara Sea's coast and the Bosporus area. In the east-west axis of the city, the built-up areas increased. Until 1970s, with the major migrations to the city, the informal settlements were increased on the coasts and the natural environment. Because of the opening of Bosporus Bridge and Fatih Sultan Mehmet Bridge, subsequently internal migrations which caused by industrial development in Istanbul and the excess of business opportunities, In 1990s, the built-up areas expanded as seen in the Figure 3. In 2000s and after, the settlements widened to even further outwards on the European and Asian sides of Istanbul (Burdett, 2009, p. 24).

Major scaled infrastructure projects (especially the mega projects which were materialized or on the process of materialization in last fifteen years, such as the Yavuz Sultan Selim Bridge (on the north of the Bosporus), the third airport on İstanbul, Kanal İstanbul project etc.), gated communities and mass housing projects are some of the reasons of this expansion. Today this expansion of the city continues increasingly.

It is possible to see these effects on the city silhouette of Istanbul. Two photographs of Beşiktaş district in 
Figure 4 and 5 including study area were taken in 1957 and 2004 Figure 4 shows the Barbaros Avenue on the construction period. In the Figure 5, the decrease of the green areas around the avenue and the increase of the high-rise buildings and skyscrapers around the avenue and Büyükdere Street are remarkable.

Some of the administrative decisions which restrict the structuring and the heights of constructions are explained below.

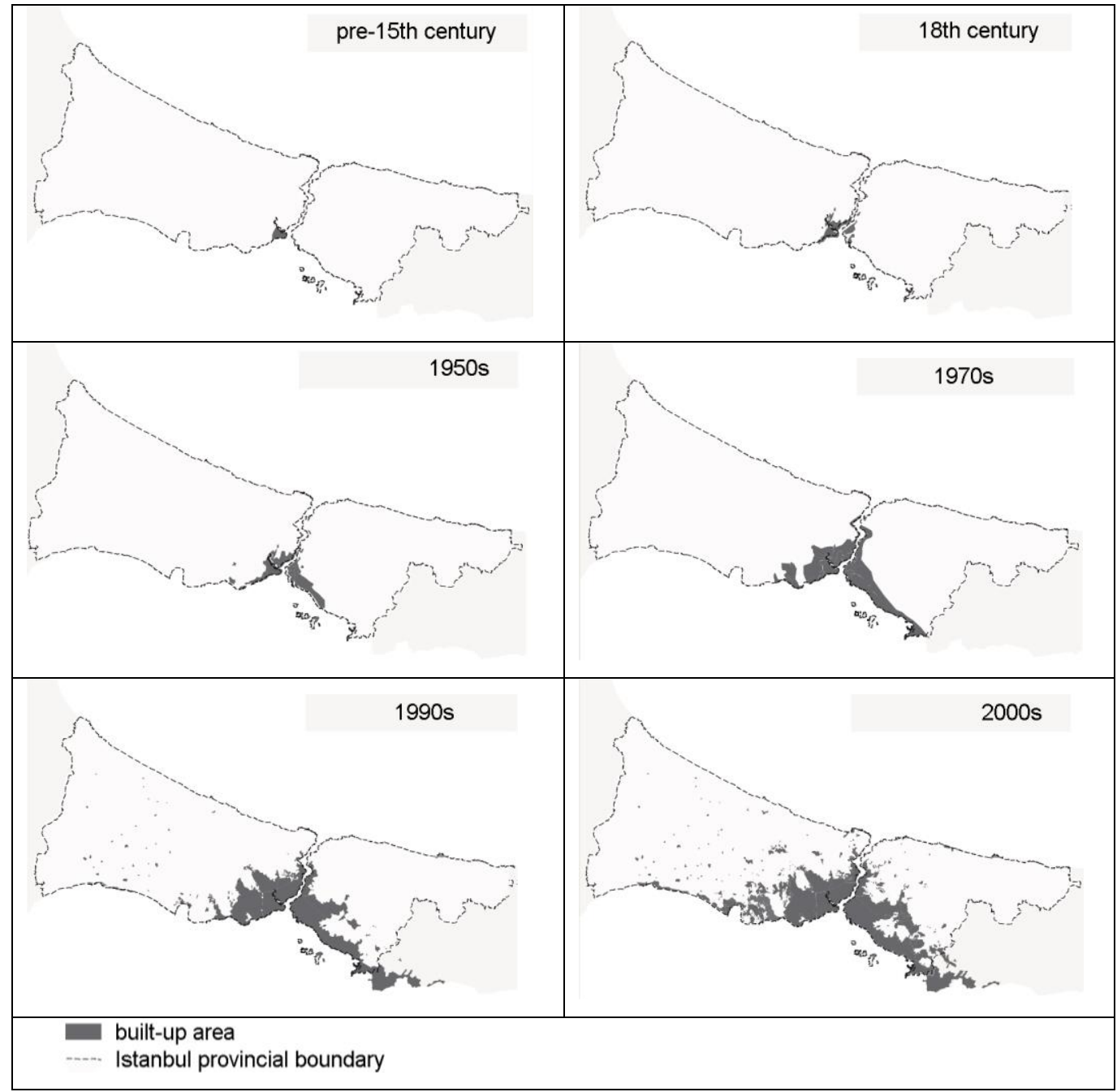

Fig. 3. Historical Evolution of Istanbul's Urban Settlement (Burdett, 2009, p. 24)
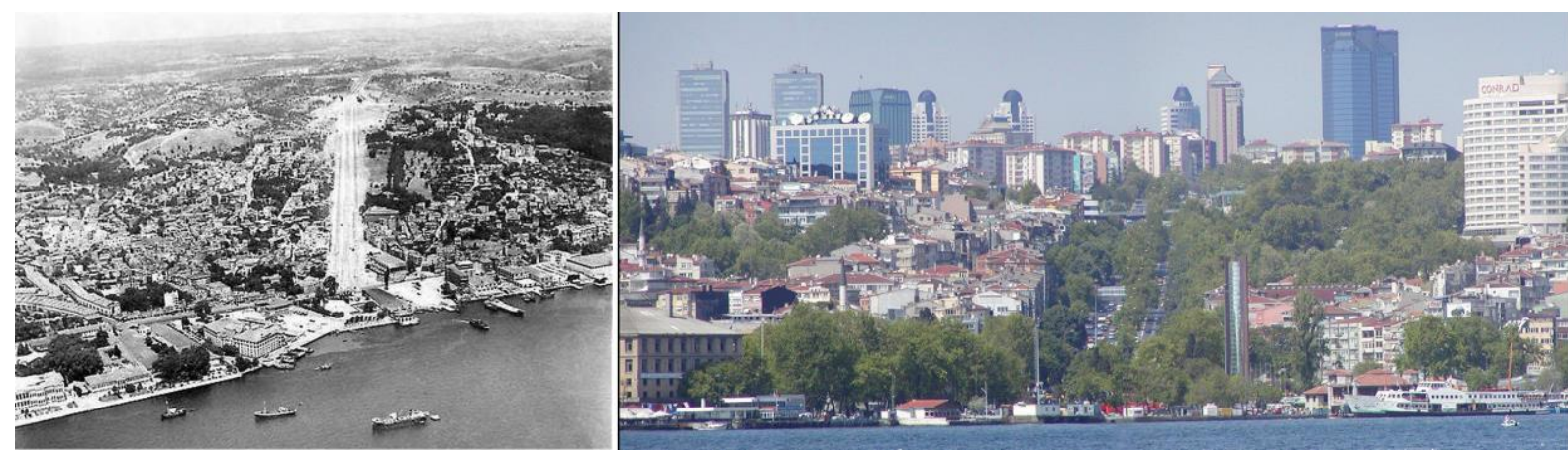

Fig. 4. (on the left) Barbaros Avenue on building process, 1957 (http://diriklik.com/eskiistanbul/cumhuriyet/cumhuriyet2/besiktas02.jpg)

Fig. 5. (on right) Barbaros Avenue, 2004 (http://wowturkey.com/tr15/Burc_yildiz_yokusu.jpg) 
In the Bosphorus area of Istanbul, in order to preserve the existing green areas and the historic areas, one of the most notable restrictions on construction is the Bosphorus Law adopted in 1983. (The Official Gazette, 1983) The Bosphorus area was divided into four regions: the coastline, the front-view, the back-view, and the effect regions. The coastal region runs along the coast line from Üsküdar - Ortaköy all the way to Rumeli Feneri - Anadolu Feneri. The front-view region includes some regions neighboring the Bosphorus coast line in need of preservation and forms the silhouette seen from the Bosphorus. The back-view region includes the areas between the front-view and the effect regions. Finally, the effect regions lie outside the front- and back-view regions and is affected by the Bosphorus coast line. It has a second level of classification into the regions that connect to the countryside and the regions that connect to the city (Bosphorus Law [BL], 1983; article 2). According to the law, housing is permitted in the back-view region if Floor Area Ratio (FAR) is at most $15 \%$ and four floors high ( $\mathrm{H}=12.50 \mathrm{~m}$. height). In the effect region, FAR is also restricted to $15 \%$, but five floors $(H=15.50 \mathrm{~m}$. height) are allowed at the most ( $\mathrm{BL}, 1983$, article 10). The rules governing the backview and the effect regions provide the background for the governance for the front region and the law affects the silhouette as it restricts the height of buildings, although the limits are not given in relation to sea level, i.e., the slope is not taken into account. Also under this law, any areas in the Bosphorus and front-view regions that have not yet been built up have been given a green area status, and construction is now forbidden (BL,1983, provisional article 4). Nonetheless, in areas outside of the Bosphorus region, construction can continue as much as Construction Law (The Official Gazette,1985) and the articles in related regulations permit.

Another regulation which limits the height of construction in Istanbul is the "Management Plan of Historic Peninsula" or (MPHP). It is a part of UNESCO Agreement for the Protection of World Cultural and Natural Heritage. The management plan area boundaries have been specified as "the whole historic peninsula" which includes some areas outside of the four zones (Süleymaniye, Zeyrek, Archeological Park, Land Walls) which are listed on the World Heritage List as "The Historical Areas of Istanbul." Two regions are mentioned in the MPHP: the historical peninsula boundaries and an offered buffer zone (MPHP, 2011, pp.12-14). According to this management plan, construction height is limited to $6.5 \mathrm{~m}$ in the area within the Land Walls. In regions $40 \mathrm{~m}$ above sea level, three floors is the limit. The importance of the Environmental Impact Assessment report (EIA) has been cited for its application to projects that have been found suitable by the EIA report and will be permitted (MPHP, 2011, p.370)

In addition, construction in the city center of Istanbul has increased in the last ten years. The Istanbul Association of Architects in Private Practice in its "Mega Istanbul" study mentions many projects that are considered "mega" due either to their urban scale or the footprint they will leave on the environment. Among these, the Zorlu Center and Tepeüstü Urban Transformation project (Mall of Istanbul) are the most remarkable for their urban mass magnitude (Project List, megaprojeleristanbul.com) Zorlu attracts more attention between the two; first, because of its central location in the city and second, because it has been criticized for lacking harmony with the local urban texture (Bilgin, 2014).

\section{FIELD STUDY}

People living in a city can be classified as settled or permanent dwellers and there are also temporary dwellers. Settled dwellers are the people who have lived in the city for a while, have integrated into the common culture of the city, and have become citizens. Temporary dwellers are people who come to the city for a purpose (tourism, trade, education, health, etc.), stay for a particular length of time and then leave to return to their homes elsewhere. The scope of this study included an analysis of the relationship between the settled citizens and the city, the problems that are caused by different types of constructions that are changing the skyline during the rapid growth of the metropolis of Istanbul, a diagnosis of the reasons why the current texture is not pleasing, and an attempt to form a conceptual picture of an ideal skyline. These are some of the questions we tried to answer:

What is the contentment level of the citizens regarding the current skyline of Istanbul?

Are the changes negative or positive in the opinion of the citizens?

What are the elements that citizens like, dislike, or want to change?

Is there a difference between the point of view and contentment level of architects and citizens from other professions?

As discussed already, the questionnaire of open-ended and close-ended questions and a semantic differential scale were administered to 60 subjects from two different groups. The first group consisted of architects, interior-designers, city planners, and landscape architects, and the other were 30 people from other professions. The subjects of the first group were chosen according to a ratio of the number of members 
of chambers of professions (number of members of Union of Chambers of Turkish Engineers and Architects, 2015). The number of male and female participants was equal.

The Zincirlikuyu district was the study area (Büyükdere Street and Barbaros Avenue cross). During the day, the area is a highly populated business district. At the same time it neighbors some low-population residential zones (like Levazım Region) with blocks of housing. The layering caused by the different types of constructions can be seen from the Beşiktaş coast.

The city is lively and active in nature. Visual data taken from the city can also be active or stable such as video clips and photographic images. The skyline here is an image that is mostly stable. The elements reflected in the skyline are sharp, strong, and definite. That is why apart of the skyline of Istanbul was chosen as study area and the data for evaluating it was made up of photo images rather than motion, depending on the method. An intersection of distant and close city skylines was chosen. In this scale of city, construction can be evaluated in its natural environment, design details can generally be seen, and natural and built environmental elements are relatively clear. The first part of the questionnaire collected demographic information. In the second part, respondents were shown a colored and panoramic photo of the area and asked to evaluate the photo using five semantic differential scales according to adjective pairs. Also they were asked open-ended questions about the things they liked and disliked about the skyline and to provide the reasons for their responses. Finally, they were asked to describe the things they would like to change in the skyline.

\section{FINDINGS AND DISCUSSION}

In both groups, $43 \%$ were male and $57 \%$ were female. All the subjects had lived in Istanbul for at least five years.

Table 1. Remarkable Elements of the Skyline

\begin{tabular}{|c|c|c|c|c|}
\hline \multirow{2}{*}{} & \multicolumn{2}{|c|}{ Architects } & \multicolumn{2}{c|}{ Other Professions } \\
\cline { 2 - 5 } & Number of People & $\%$ & Number of People & $\%$ \\
\hline Skyscrapers & 25 & 83.33 & 20 & 66.67 \\
\hline $\begin{array}{c}\text { Non-proportional/ Irregular/ } \\
\text { Unbalanced/ Disharmonious/ Crowded }\end{array}$ & 14 & 46.67 & 20 & 66.67 \\
\hline Lack of green space & 11 & 36.67 & 5 & 16.67 \\
\hline Disharmony of old/new & 9 & 30.00 & 13 & 43.33 \\
\hline
\end{tabular}

$83.33 \%$ of architects said skyscrapers, $46.67 \%$ said it was the irregularity of the overall image, $36.67 \%$ found a lack of green space, and $30 \%$ found there to be disharmony between old and new construction, as remarkable elements in the skyline. $66.67 \%$ of respondents from other professions also said skyscrapers, $67 \%$ said the irregularity of the overall image, $16.67 \%$ disliked the lack of green space, and $43.33 \%$ agreed that there was disharmony between old and new construction. The elements that both groups found remarkable were skyscrapers, and then the lack of proportionality in the skyline.

They also cited it was irregular, unbalanced, discordant and congested skyline. In their responses, subjects used the words for skyscrapers; modern, non-proportional, disharmonious, unplanned urbanization, overcrowded, concrete jungle, extremely high, enormous, and seemed genuinely disturbed when talking about the most remarkable elements of the skyline (Table 1).

Table 2. Elements of the Skyline that are Liked

\begin{tabular}{|c|c|c|c|c|}
\hline \multirow{2}{*}{} & \multicolumn{2}{|c|}{ Architects } & \multicolumn{2}{c|}{ Other Professions } \\
\cline { 2 - 5 } & Number of People & $\%$ & Number of People & $\%$ \\
\hline Low-rise structures in the foreground & 15 & 50.00 & 9 & 30.00 \\
\hline There is no structure to like & 10 & 33.33 & 10 & 33.33 \\
\hline Skyscrapers & 5 & 16.67 & 11 & 36.67 \\
\hline Green spaces & 6 & 20.00 & 3 & 10.00 \\
\hline
\end{tabular}


Of the architects, $50 \%$ preferred low-rise structures in the foreground and $33.33 \%$ said that there was nothing to like in the skyline. As the last thing $16.67 \%$ said they liked the skyscrapers. Interestingly, the most liked elements of the other professionals were skyscrapers and the least liked element was green spaces.

The reason architects liked low-rise structures was because "they relate better to green spaces and natural topography; seem calmer, more humanistic, warmer, closer to human scale, consistent, and in balance with the city scale, more spacious, more regular, safer in case of earthquake; they don't effect the skyline or the view, don't block out the sun, and they give soul to the city." Skyscrapers were thought to "help the skyline look livelier and the city look more developed as long as there were fewer of them, they were properly located, and looked more unique." Most said they were liked because "skyscrapers provide a modern look, help the city look rich, and encourage more trade."

Low-rise structures were liked by people of other professions because "they were compatible with the topography and each other, closer to human scale, had green spaces around them, their impacts on nature and human were minimal, and neighborhood relations were more nurtured by them." Skyscrapers were liked because "they were needed, regular, modern, and better-planned; they made the density of the neighborhood homogenous, and gave the city a nicer skyline." The respondents from other professions found skyscrapers more esthetically pleasing when looked at individually (Table 2).

Table 3. Elements that Disorder the Skyline

\begin{tabular}{|c|c|c|c|c|}
\hline \multirow{2}{*}{} & \multicolumn{2}{|c|}{ Architects } & \multicolumn{2}{c|}{ Other Professions } \\
\cline { 2 - 5 } & Number of People & $\%$ & Number of People & $\%$ \\
\hline Skyscrapers & 29 & 96.67 & 26 & 86.67 \\
\hline $\begin{array}{c}\text { Zorlu Center /Tat Towers etc. } \\
\text { (Specifically named by subjects) }\end{array}$ & 12 & 40.00 & 12 & 40.00 \\
\hline $\begin{array}{c}\text { There is no aesthetic skyline to be } \\
\text { disordered }\end{array}$ & 1 & 3.33 & 3 & 10.00 \\
\hline
\end{tabular}

Skyscrapers were listed as the most dominant element that caused a sense of disorder in the skyline and $40 \%$ of each group specifically named structures like Zorlu, Tat Towers and Metrocity as examples. In both groups there were people who claimed that there was no skyline to speak of, so there was nothing to be ruined.

Zorlu was the most disliked by architects because they perceived it as "incompatible with the overall structural texture, looked horizontally and vertically huge, looked like a massive block and an extension of the skyline, overshadowed other structures, and affected the skyline negatively." Respondents said that skyscrapers damaged the skyline because "they damage the historic texture of Istanbul, limit the view, block out the sky, the sunlight, and the natural air flow, occupy space that would be green instead, affect neighborhood relations badly, and were such massive blocks that they are incompatible not only on a human scale, but even on a city scale, and not related to our culture."

Zorlu was not liked by the people from other professions either, because "it is incompatible with the area and its environment, horizontally and vertically huge, and looks like a massive block." They thought skyscrapers were damaging to the skyline because they create a wall effect, they limit the sun light and the wind, and there is no coherence or common language among the buildings." (Table 3)

Table 4. Formal Evaluation of the Skyline

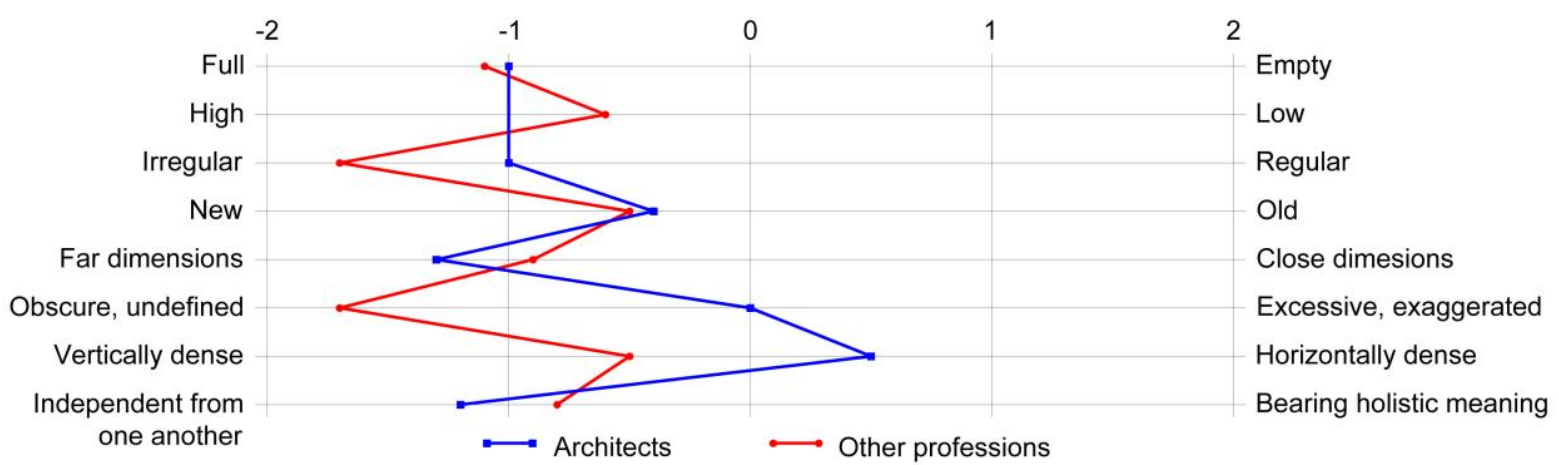

In a 5-pointed semantic differential scale using adjective pairs, the subjects were asked to evaluate the form of the skyline. Both groups described it as generally full, high, and irregular, scaled in an unbalanced way, 
and lacking a common language. In this table, the architects found the skyline more balanced compared to the other group (Table 4).

Table 5. Experiential Evaluation of the Skyline

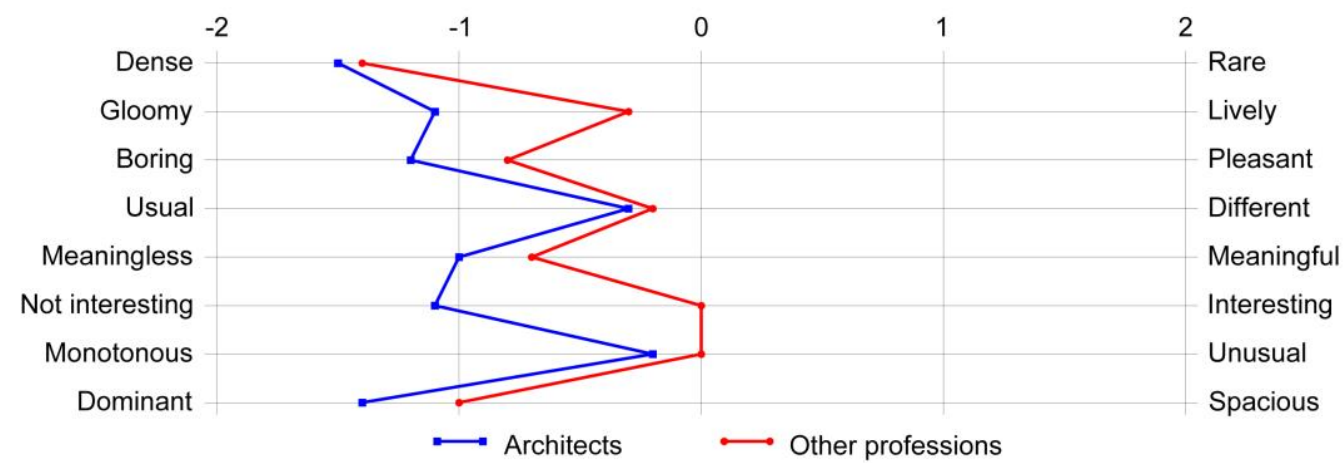

However, on the experiential evaluation scale, both groups evaluated the skyline negatively and it was the architects who had more negative impressions than other group (Table 5).

Table 6. Social Evaluation of the Skyline

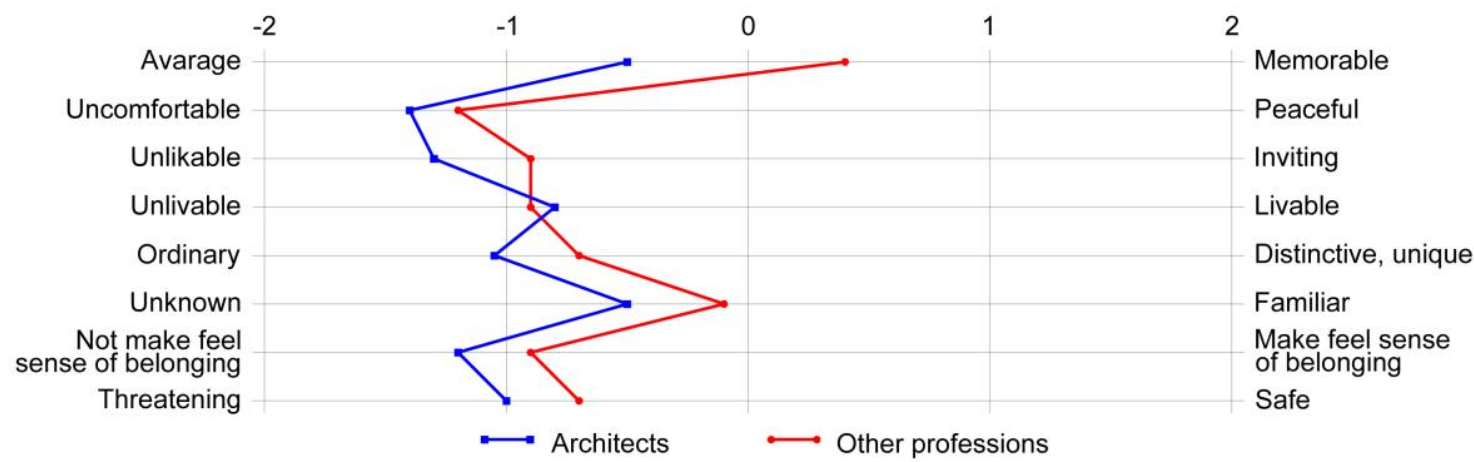

Both groups evaluated the skyline as socially negative. They agreed that it was uncomfortable, unlikable, and threatening; didn't make them feel a sense of belonging, and it was not a place where they would like to live. Again, the architects expressed the more worried perspective than the other group (Table 6).

Table 7. Elements that are wanted to be changed

\begin{tabular}{|c|c|c|c|c|}
\hline \multirow{2}{*}{} & \multicolumn{2}{|c|}{ Architects } & \multicolumn{2}{c|}{ Other Professions } \\
\cline { 2 - 5 } & $\begin{array}{c}\text { Number of } \\
\text { People }\end{array}$ & $\%$ & $\begin{array}{c}\text { Number of } \\
\text { People }\end{array}$ & $\%$ \\
\hline More Green Spaces & 18 & 60.00 & 14 & 46.67 \\
\hline More Balanced Height of the Structures & 13 & 43.33 & 12 & 40.00 \\
\hline $\begin{array}{c}\text { Removing Skyscrapers-Structures that Ruin the } \\
\text { Skyline }\end{array}$ & 8 & 26.67 & 6 & 20.00 \\
\hline $\begin{array}{c}\text { Removing Low-rise Structures } \\
\text { There Being Compatible Structures with Each } \\
\text { Other and the Texture }\end{array}$ & 8 & 26.67 & 6 & 20.00 \\
\hline Horizontal Structuring instead of Vertical One & 4 & 13.33 & 5 & 13.33 \\
\hline
\end{tabular}

What the architects and the other group talked about most was the need for "more green spaces." Next, was the necessity of a more balanced height of the structures, removing skyscrapers, or trimming the parts that are higher than the level of the rest of the skyline were mentioned most. However, of the architects, $26.67 \%$ said that they would want to remove low-rise structures from the skyline. Of the other group of professionals, $20 \%$ agreed with this opinion.

Architects stated that "structures should be more suitable for the topography and responsive to local data, 
skyscrapers should be compatible with the environment, the skyline should avoid exaggeration in vertical and horizontal aspects, there should be more green spaces instead of high-rise buildings, structures that cause the city to be over crowded in certain places and create a wall effect should be avoided, skyscrapers should be limited to a certain number floors as well as height, if vertical architecture is needed, it should be created in a more orderly fashion, there should be more spaces designed explicitly for human interaction to stimulate the growth and sustainability of neighborhood cultures, in short, more social spaces." What is more, in their opinion, the skyline was not distinctive enough to convey an identity.

People from other professions that participated stated that "the height of the structures should be gradually increased. They should be people-based and well-planned. Houses should have gardens and green spaces should be more dominant than structures. The architecture should reflect local culture. For example, there should be more mosques and they should be more remarkable. The depth of the city and the view of the skyline should be increased." They thought that skyscrapers are a better solution and suggested that "old structures should be modernized, there should be more distance between the buildings, skyscrapers should be more orderly, vertical depth should be decreased as more skyscrapers are built for a gradual separation between high and low, old and new.

\section{CONCLUSION AND SUGGESSTIONS}

As is revealed by the results of this study, local residents of the city, regardless of their profession were disturbed by the new construction in the city and the layered skyline that is evolving from it. Citizens expressed discomfort with the formal characteristic of the city and find it negative in experiential way. These feelings and perceptions leave them feeling alienated from the city rather than feeling they are a part of this portrait. Unfortunately, they find the city repellent and threatening. It is true that the perceptions of the land use professionals like the architects are more negative and worried about this problem than the respondents from the other professions. Consequently, it is seen that city perception of architects and other professions are different.

The greatest complaint was about the lack of green space. They all expressed a need for more of it to balance the view of the skyline. This is an issue of urban texture.

Skyscrapers and high buildings are more liked by people from other professions; they are thought to be esthetical as individually. What is more, skyscrapers make impressions as "modern, durable, secure, having good infrastructure, rich and suitable for the city" in citizens' perception. However, architects do not like the skyscrapers. Especially Zorlu is thought to be incompatible with the city scale and away from being esthetical. Although there are differences between the professional disciplines, both groups of the citizens do not think that vertically and horizontally dominant and holistic masses in the skyline are esthetical.

There is a clear need to revise construction designs to be more compatible among themselves and improve planning for better infrastructure and social spaces where the natural environment is allowed to be more dominant. Designs should be made according to local data that indicates an appeal for a more gradual and obvious transition between building heights. People want a balanced environment where scales and ratios are based on positive perceptions and are compatible with and respectful of old construction. Surely allowing residents to have more participation in the changes that are happening in the city would give them a chance to feel more like the city belonged to them, and they belonged to the city. To implement such interactions, new local policies should be created; more balanced plans should be made in terms of density and vertical structuring at both lower and higher scales. In conclusion, this study is presented as a basis for further studies to design cities with features that are compatible within themselves and where people can live more contentedly with a sense of belonging to their environment.

\section{REFERENCE LIST}

Aksoy, F., (2009). Kent Siluetinin Değerlendirilmesi: 'Boğaziçi Yerleşkesi Örneğinde İncelenmesi'. MSc. Thesis, Yıldız Techinical University, Faculty of Architecture, İstanbul.

Barbaros Avenue in 1957, Photos of Old Istanbul, http://diriklik.com/eskiistanbul/cumhuriyet/cumhuriyet2/besiktas02.jpg/ (01.01.2016)

Barbaros Avenue in 2004, Wow Turkey, One Million Photos of Turkey, İstanbul Barbaros Bulvarı (Yıldız Yokuşu) http://wowturkey.com/t.php?p=/tr15/Burc_yildiz_yokusu.jpg/ (04.02.2016)

Bayramoğlu, N. (2010). Kullanıcı Algısı Bağlamında Kentsel Kimlik: Barbaros Bulvarı-Büyükdere Kentsel Aksı. . MSc. Thesis, ITU, Faculty of Architecture, İstanbul. 
Bilgin, İ. (2014). Zorlu Vakası, mimdap.org, http://www.mimdap.org/?p=142190 (30.04.2014)

Bosphorus Law (1983). The Official Gazette of Rebuplic of Turkey, 18229, 22.11.1983. http://www.mevzuat.gov.tr/MevzuatMetin/1.5.2960.pdf (10.12.2015)

Bostancı, S. H. (2008). Kentsel Siluetinin Entropi Yaklaşımı ile Değerlendirilmesi. Phd. Thesis, ITU, Faculty of Architecture, İstanbul.

Burdett, R., ed. (2009) İstanbul: Kesişimler Şehri. Urban Age, İstanbul.

Cansever, T. (2015). İstanbul'u Anlamak (4th Ediition). İstanbul: Timaş Yayınları.

Construction Law (1983). The Official Gazette of Rebuplic of Turkey, 18749, 09.05.1985. http://www.mevzuat.gov.tr/MevzuatMetin/1.5.3194.pdf (10.12.2015).

Erdönmez, M. E., Akı, A. (2005). Açık Kamusal Kent Mekanlarının Toplum İlişkilerindeki Etkileri. Megaron YTU Architecture Faculty e-Journal 1 (1) 67-87. http://www.megaron.yildiz.edu.tr/wordpress/papers/Megaron_01-01-07_Erdonmez.pdf/ (10.12.2015).

Hasol, D. (2008). Ansiklopedik Mimarlık Sözlüğü (10th Edition). İstanbul: Yem Yayın, 422.

Lynch, K. (1960). The Image of City, The MIT Press, Cambridge, 70-86.

Management Plan of Historic Peninsula of İstanbul (2011). İstanbul Alanları Alan Yönetim Başkanlığı, http://www.alanbaskanligi.gov.tr/files/Y\%C3\%B6netim\%20Plan\%C4\%B1_24\%C5\%9Fubat2012_k.pdf (08.12.2015).

Mega Istanbul, Project List, The Istanbul Association of Architects in Private Practice, http://megaprojeleristanbul.com/ (09.12.2014).

Ocakçı, M. (1994). Kimlik Elemanlarının Şehirsel Tasarıma Yönlendirici Etkisi. Kentsel Tasarım ve Uygulamalar Sempozyumu, Kentsel Tasarıma Ekolojik Yaklaşım, 239-245, İstanbul.

Ocakçı, M. (1995). Şehir Kimliği ve Çevre İlişkileri, Kent ve Çevre Planlamaya Ekolojik Yaklaşım. 17. Dünya Şehircilik Günü Kolokyumu, 163-170, İstanbul.

Önem, A. B., Kılınçarslan, İ. (2005). Haliç Bölgesinde Çevre Algılama ve Kentsel Kimlik. İtü Dergisi/a Mimarlık, Planlama ve Tasarım, 4 (1), 115-125.

Oral, M. (2013). Mimarlık \& Estetik, Mimarlık Estetik Iliş̧isi. Kastel, 1 (1), 17-19.

Özdeş, G. (1985). Şehircilik, Şehir - Şehirlerin Fonksiyon Bölgeleri, ITT̈̈ Matbaası, 15-40.

Rapaport, A. (1977). Human Aspects of Urban Form:Towards a Man-Environment Approach to Urban Form an Design Pergamon Press, Newyork, 20-35.

Şentürer, A. (2004). Mimarlıkta, Estetikte, Tasarımda, Eğitimde Eleştirel Yaklaşım, Yapı Yayın, İstanbul.

Topçu, K. D. (2011). Kent Kimliği Üzerine Bir Araştırma: Konya Örneği. Internetional Journal of Human Sciences, 8(2), 1048-1072.

Union of Chambers of Turkish Engineers and Architects (Members of Union of Chambers of Turkish Engineers and Architects) number of members, 2015, Tmmob Üye Sayısı 467 Bini Aştı. http://www.tmmob.org.tr/icerik/tmmob-uye-sayisi-467-bini-asti/ (12.12.2015). 